International Journal of Engineering \& Technology, 7 (4) (2018) 2575-2580
International Journal of Engineering \& Technology
SPC
Website: www.sciencepubco.com/index.php/IJET
doi: $10.14419 /$ ijet.v7i4.16698
Research paper

\title{
Investigation The Exergy Performance of a Forced Draft Wet Cooling Tower
}

\author{
Fadhil Abdulrazzaq Kareem ${ }^{1}$ *, Mustafa J. Al-Dulaimi ${ }^{2}$, Noor Samir Lafta $^{1}$ \\ ${ }^{1}$ Institute of Technology Baghdad, Middle Technical University, Baghdad, Iraq \\ ${ }^{2}$ Department of air conditioning and Refrigeration Engineering Technologies, Al Esraa university collage, Baghdad, Iraq \\ *Corresponding author E-mail: Mustafa@esraa.edu.iq
}

\begin{abstract}
The performance of a forced draft wet cooling tower was investigated experimentally and the calculation was performed by applying second law of thermodynamics (exergy analysis). The mathematical model was developed by using engineering equation solver (EES) software. The results show that the chemical exergy of air increases from the bottom to the top of the cooling tower, the thermal exergy of air decreases from bottom to the top of the cooling, the exergy of water decreases from top to the bottom of the cooling tower. The exergy destruction decreases from bottom to the top of the cooling tower, and the exergy efficiency decreases from top to the bottom of the cooling. The exergy destruction tends to increase as the inlet wet bulb temperature increases while the exergy efficiency decreases. As water-air flow rate ratio increases the exergy destruction increases while the exergy efficiency decreases. The results show that there is an inverse proportional be-tween exergy destruction and exergy efficiency.
\end{abstract}

Keywords: Exergy Efficiency; Cooling Tower; Exergy Destruction of Cooling Tower; Thermal Exergy; Chemical Exergy.

\section{Introduction}

Cooling towers are commonly used in large thermal systems, such as industrial power generation units, refrigeration and air conditioning plants, chemical and petrochemical industries to dissipate process heat. The heat absorbed from such systems is dissipated to the atmosphere using the cooling tower. The heat is dissipated by convection between drops of water and external air and also by evaporation of small water droplets so that heat and mass transfer occurs in cooling tower [1]. Exergy analysis is a valuable thermodynamic strategy for evaluating and improving the efficiency of the systems so the exergy efficiency and exergy destruction, it can be used to optimize the economic performance of the systems [2]. T. Muangnoi [3] used the exergy analysis to indicate exergy and exergy destruction through the cooling tower. The model of the analysis was compared with experimental data. The results show that water exergy increases continuously from bottom to top of the cooling tower. Also it is noted that the exergy of the air increases continuously from bottom to top of the cooling tower. The results show that the highest exergy destruction is located at the bottom of the cooling tower, and finally the amount of exergy absorbed by air is smaller than that supplied by water. A. Ataei [4] introduced a mathematical model to predict the performance of a counter flow wet cooling tower using exergy analysis. The amount of exergy supplied by water is larger than that absorbed by air. The exergy corresponded to convective transfer decreases from bottom to the top of the cooling tower while the amount of that corresponding to evaporative heat transfer increases from the bottom to the top. The results showed that the exergy of air via convection has been was an increase from the bottom to the top of the cooling tower where the exergy of air via evaporation was decreasing from the bottom to the top of the cooling tower. On the other hand, the water exergy decreases from the top to the bottom of the tower.
N. Bozorgan [5] presented a mathematical model to analyze the exergy of a counter flow wet cooling tower. The obtained results showed that the water makes more exergy than air. The results also showed that the water exergy decreases from the top to the bottom of the cooling tower, while the exergy of air increases from the bottom to the top of cooling tower.

Khan et al [6] investigated the heat and mass transfer mechanism and performance characteristics of counter flow cooling towers using a detailed theoretical model. In this model, an approximate equation was used to calculate wet air enthalpy. This equation was obtained from the thermodynamic properties of saturated air-water vapor mixture. To obtain proper results calculating accurately the properties of wet air appears to be essential.

Khalifa [7] proposed a mathematical model based on Merkel theory with some simplifications to analyses the exergy of a counter flow Induced draught cooling tower. The result showed that exergy of water decreases from the top to the bottom of the cooling tower, the thermal exergy of air decreases from the bottom to the top of the cooling tower while the chemical exergy of the air increases from the bottom to the top of the cooling tower. Also, the results showed that the exergy destruction increases from the bottom to the top of the cooling tower.

Q. S. Mahdi 2016 [8] in this study the performance analysis on the cooling tower depended upon the second law of thermodynamics, a prototype of the cooling tower was manufactured with capacity of $9 \mathrm{~kW}$, the result shows that the exergy destruction was depended on the inlet wet bulb temperature as the wet bulb temperature increase due to increase in the exergy destruction and this effect on the exergy efficiency, as the wet bulb temperature increase due to decrease in the exergy efficiency, and it is shown that the exergy destruction was directly proportional to water flow rate, air flow rate, and inlet cooling water temperature whereas.

This research applies exergy analysis to investigate the performance of a forced draft wet cooling tower in Iraqi climate. The 
research investigates the impact of inlet air wet bulb temperature (WBT) and the ratio of water mass flow rate to air mass flow rate $(\mathrm{L} / \mathrm{G})$ ratio on the performance of such towers.

\section{Mathematical model}

Figure 1 shows the schematic diagram of the cooling tower. The water flows downward and the air flows upward. The following assumptions are considered when the cooling tower is modeled:

1) The cooling tower is divided into $100 \mathrm{CV}$ for thermal and mass analysis

2) Steady and local uniform (uniform at each cross-sectiona area) flow

3) The Heat transfer from the tower wall to the surrounding is neglected

4) The Heat transfer from pump and fan to the water and air is neglected

5) The changes in potential and kinetic energies are neglected

6) The cross-sectional area of the tower is constant

7) The specific heats of water and dry air specific heats are constant.

8) One dimensional temperature variation, i.e. temperature change in vertical direction.

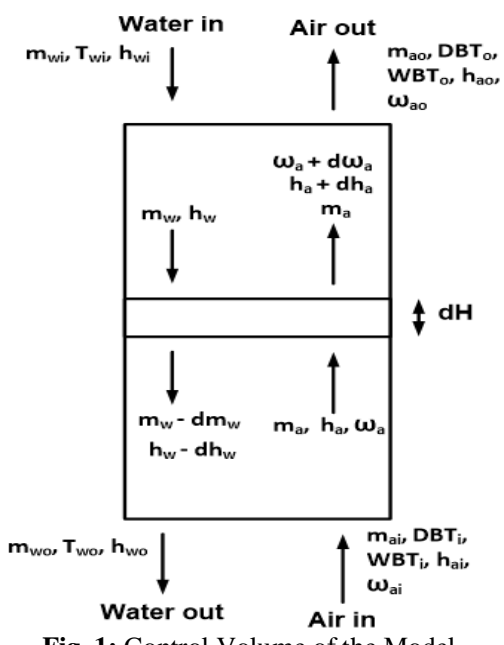

Fig. 1: Control Volume of the Model.

The mass balance of control volume is [3-5]

$\mathrm{dL}=\mathrm{G} * \mathrm{~d} \omega$

And the energy balance of the control volume is:

$\mathrm{G} * \mathrm{dh}_{\mathrm{a}}=\mathrm{L} * \mathrm{C}_{\mathrm{w}} * \mathrm{~T}_{\mathrm{w}}+\mathrm{dL} * \mathrm{C}_{\mathrm{w}} * \mathrm{~T}_{\mathrm{w}}$

Substituting eq (1) into eq (2)

$\mathrm{G} * \mathrm{dh}_{\mathrm{a}}=\mathrm{L} * \mathrm{C}_{\mathrm{w}} * \mathrm{~T}_{\mathrm{w}}+\mathrm{G} * \mathrm{~d} \omega * \mathrm{C}_{\mathrm{w}} * \mathrm{~T}_{\mathrm{w}}$

The change of air enthalpy in the control volume is

$\mathrm{dh}_{\mathrm{a}}=\frac{\mathrm{L}}{\mathrm{G}} * \mathrm{C}_{\mathrm{w}} * \mathrm{~T}_{\mathrm{w}}+\mathrm{d} \omega * \mathrm{C}_{\mathrm{w}} * \mathrm{~T}_{\mathrm{w}}$

The total amount of heat transfer between air and water can be written as a function of latent heat and sensible heat as [7-9]:

$\mathrm{dq}_{\mathrm{t}}=\mathrm{dq}_{\mathrm{l}}+\mathrm{dq}_{\mathrm{s}}$

The latent heat can be calculated from [7]:

$\mathrm{dq}_{1}=\mathrm{h}_{\mathrm{diff}} * \mathrm{~h}_{\mathrm{g}} * \mathrm{dA} *\left(\omega_{\mathrm{s}}-\omega\right)$

And the sensible heat can be calculated as [7]

$\mathrm{dq}_{\mathrm{s}}=\mathrm{h}_{\mathrm{c}} * \mathrm{dA} *\left(\mathrm{~T}_{\mathrm{w}}-\mathrm{T}_{\mathrm{a}}\right)$
By substituting and simplifying equations the total heat $\mathrm{dq}_{\mathrm{t}}$ can be written as

$\mathrm{dq}_{\mathrm{t}}=\frac{\mathrm{h}_{\mathrm{c}} * \mathrm{dA}}{\mathrm{C}_{\mathrm{pm}}} *\left(\mathrm{~h}_{\mathrm{as}}-\mathrm{h}_{\mathrm{a}}\right)$

Also, the total heat transfer can be written as

$\mathrm{dq}_{\mathrm{t}}=\mathrm{L} * \mathrm{C}_{\mathrm{w}} * \mathrm{dT}_{\mathrm{w}}$

Substituting eq (9) in eq (8), the following equation can be written

$\frac{\mathrm{h}_{\mathrm{c}} \mathrm{A}}{\mathrm{C}_{\mathrm{pm}}}=\frac{\mathrm{L} * \mathrm{C}_{\mathrm{w}} * \mathrm{dT}_{\mathrm{w}}}{\left(\mathrm{h}_{\mathrm{as}}-\mathrm{h}_{\mathrm{a}}\right)_{\mathrm{m}}}$

Where $\left(h_{a s}-h_{a}\right)_{m}$ is the arithmetic-mean enthalpy difference in the control volume. In order to calculate the dry bulb temperature of the air inside the cooling tower, the inlet conditions of the entering air must be known. The balance of the rate of sensible heat transfer at any section of the cooling tower permits calculation of the air outlet [9]

The sensible heat balance can be written as

$\mathrm{G} * \mathrm{C}_{\mathrm{pm}} * \mathrm{dT}_{\mathrm{a}}=\mathrm{h}_{\mathrm{c}} * \mathrm{dA}\left(\frac{\mathrm{T}_{\mathrm{a}, \mathrm{n}}-\mathrm{T}_{\mathrm{a}, \mathrm{n}+1}}{2}-\frac{\mathrm{T}_{\mathrm{w}, \mathrm{n}}-\mathrm{T}_{\mathrm{w}, \mathrm{n}+1}}{2}\right)$

Solve for $\mathrm{T}_{\mathrm{a}, \mathrm{n}+1}$

$\mathrm{T}_{\mathrm{a}, \mathrm{n}+1}=\frac{\mathrm{T}_{\mathrm{a}, \mathrm{n}}-\frac{\mathrm{h}_{\mathrm{c}} * \mathrm{dA}}{2 * \mathrm{G} * \mathrm{C}_{\mathrm{pm}}} *\left(\mathrm{~T}_{\mathrm{a}, \mathrm{n}}-\mathrm{T}_{\mathrm{w}, \mathrm{n}}-\mathrm{T}_{\mathrm{w}, \mathrm{n}+1}\right)}{1+\frac{\mathrm{h}_{\mathrm{c}} * \mathrm{dA}}{2 * \mathrm{G} * \mathrm{C}_{\mathrm{pm}}}}$

Where $\frac{h_{c} * d A}{2 * G * C_{p m}}$ is equal to the $\frac{h_{c} * d A}{C_{p m}}$ from eq (10) divided by $2 * \mathrm{G}$

The cooling tower was divided into 100 control volume; the governing equations of the cooling tower device were design in EES.

The total exergy of the humid air can be divided into thermal exergy and chemical exergy. For steady-state psychometric process without the effect of kinetic and potential energy, and neglecting the change of pressure through the cooling tower, the thermal exergy of the air can be represented as [7-10]

$E x_{t h, C V}=G *\left[\begin{array}{c}c p_{a} *\left(T_{a, n}-T_{o}\right)-T_{o} * c p_{a} * \ln \left(\frac{T_{a, n}}{T_{o}}\right)+ \\ \omega_{a, n} *\left(c p_{v} *\left(T_{a, n}-T_{o}\right)-T_{o} * c p_{v} * \ln \left(\frac{T_{a, n}}{T_{o}}\right)\right)\end{array}\right]$

And the chemical exergy of the air can be represented as [9-6]

$E x_{c h, C V}=G *\left[\begin{array}{c}R_{a} * T_{o} * \ln \left(\frac{1+1.608 * \omega_{a, o}}{1+1.608 * \omega_{a, n}}\right)+ \\ \omega_{a, n} * R_{v} * T_{o} * \ln \left(\frac{\omega_{a, n} *\left(1+1.608 * \omega_{a, o}\right)}{\omega_{a, o} *\left(1+1.608 * \omega_{a, n}\right)}\right)\end{array}\right]$

By neglecting of the mechanical exergy of water, the total exergy of water could be expressed as [4]

$E x_{w, C V}=G * \omega_{a, n} *\left[c p_{v} *\left(T_{a, n}-T_{o}\right)-T_{o} * c p_{v} *\right.$

$\left.\ln \left(\frac{T_{w, n}}{T_{o}}\right)+R_{v} * T_{o} * \ln \left(R H_{o}\right)\right]$

The total exergy destruction represents the differences between the exergy inlet and the exergy outlet which includes thermal and chemical exergy of air and exergy of water [11]

$E x_{\text {dest.CV }}=\sum E x_{\text {in, } C V}-\sum E x_{\text {out }, C V}$

The exergy efficiency is the ratio between the exergy out and the exergy in of the cooling tower represent the actual performance of the cooling tower [7], [10], [11] 
$\eta_{\text {ex }}=\frac{E x_{\text {out }}}{E x_{\text {in }}}$

The constant values of air and water vapour are used [5]:

$c p_{a}=1.004 \mathrm{~kJ} /(\mathrm{kg} \cdot \mathrm{K}), c p_{v}=1.872 \mathrm{~kJ} /(\mathrm{kg} \cdot \mathrm{K}), c p_{w}=$ $4.19 \mathrm{~kJ} /(\mathrm{kg} . \mathrm{K}), R_{a}=1.004 .287 \mathrm{~kJ} /(\mathrm{kg} . \mathrm{K}), R_{v}=$ $0.461 \mathrm{~kJ} /(\mathrm{kg} . \mathrm{K})$.

\section{Description of the cooling tower}

The cooling tower used in this investigation is shown in Figure 2. The dimensions of the test rig are $0.2 \mathrm{~m}$ in length, $0.2 \mathrm{~m}$ in width and $0.8 \mathrm{~m}$ in height. The cooling tower is filled with 12 cartons packing fills; the height of each one is $5 \mathrm{~cm}$. The water flow is induced by using a centrifugal water pump. The flow meter is calibrated with a reference flowmeter. The spray nozzles are distributed equally in order to ensure uniform spreading of water on the packing fills. The spray nozzle is a piece of pipe with 4 holes of diameter $2 \mathrm{~mm}$. The flow of air is induced by using a blower and a damper is used to control the flow rate of the air through the rig. The flow rate of air is measured by using a manometer on the sides of an orifice. The orifice is manufactured according to the British standards. The manometer is calibrated with reference digital manometer. The orifice is fixed after a certain distance from the blower. A flow-meter fixed on the discharge pipe of the pump is used to measure the flow rate of the water. Six thermocouples of type $\mathrm{K}$ are used to measure the temperatures. Four thermocouples are used to measure the air dry bulb and wet bulb temperature at the inlet and outlet, while two thermocouples are used to measure the temperature of the water at the inlet and outlet. The Calibration of thermocouples are shown in figure 3 . The relation between the reference temperature and that of thermocouples is linear which indicates there is no or a very small error in thermocouples reading. The exhaust air from the cooling tower has a high humidity so that a flexible duct connected to the tower discharge e exhaust air to the surrounding.

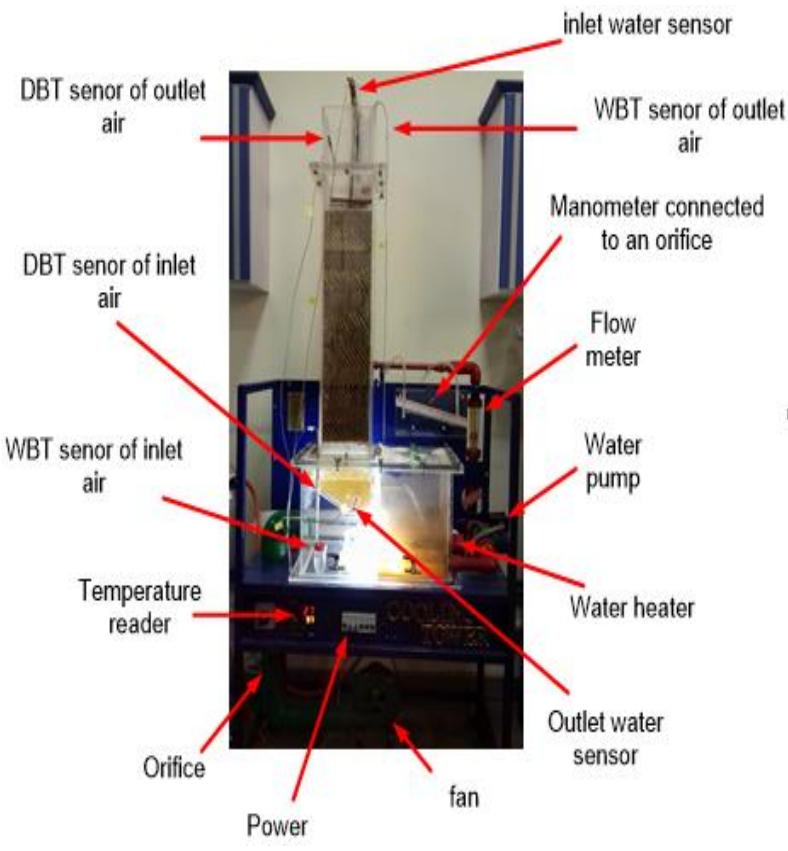

Fig. 2: The Test Rig.

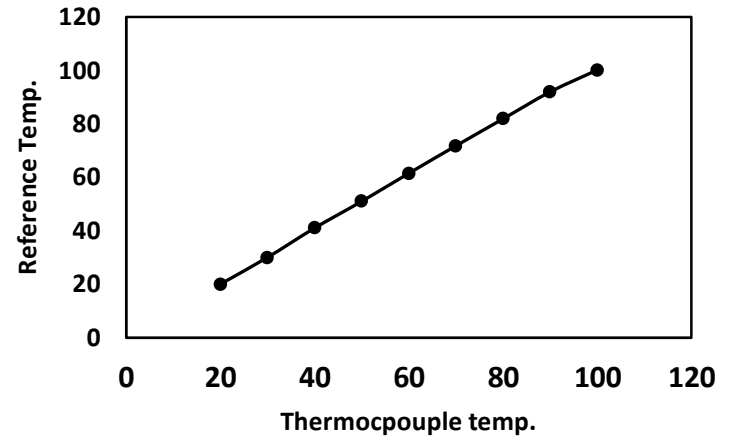

Fig. 3: Thermocouples Calibration.

\section{Result and discussion}

In the present work, the exergy analysis is employed to investigate effect of inlet air wet bulb temperature (WBT) and the ratio of water mass flow rate to air mass flow rate $(\mathrm{L} / \mathrm{G})$ on the performance of a forced draft wet cooling tower.

Figures 4, 5 and 6 present the effect of inlet air wet bulb temperature (WBT) and the ratio of water mass flow rate to air mass flow rate $(\mathrm{L} / \mathrm{G})$ on the chemical exergy of air. The results show that the chemical exergy of air increases upward from the bottom to the top of the cooling Tower. This is because the chemical exergy of air is strongly affected by air moisture and the moisture increases upward. Also it can be seen that the chemical exergy of air increases with the increase of inlet air wet bulb temperature (WBT) and the ratio of water mass flow rate to air mass flow rate. This can be attributed to the increase in thermal exchange causes by evaporation.

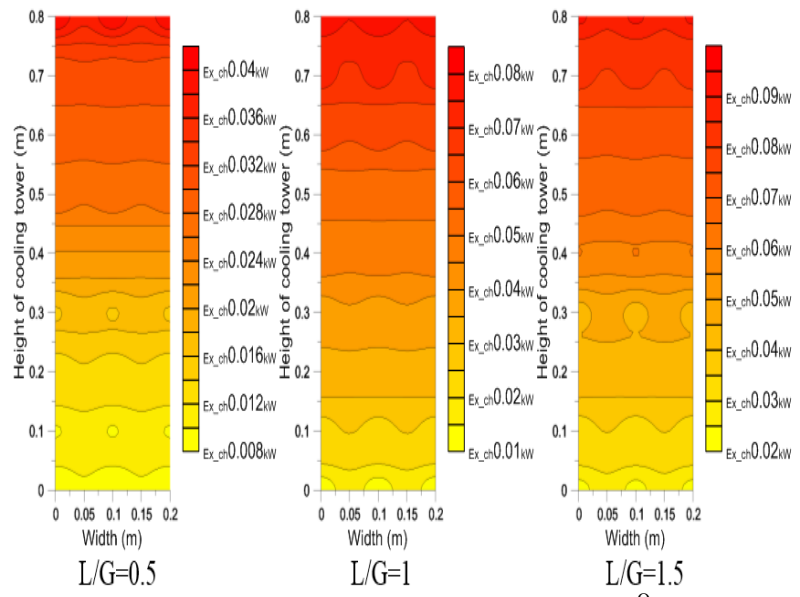

Fig. 4: Chemical Exergy of Air for $\left(\mathrm{WBT}=18^{\circ} \mathrm{C}\right)$

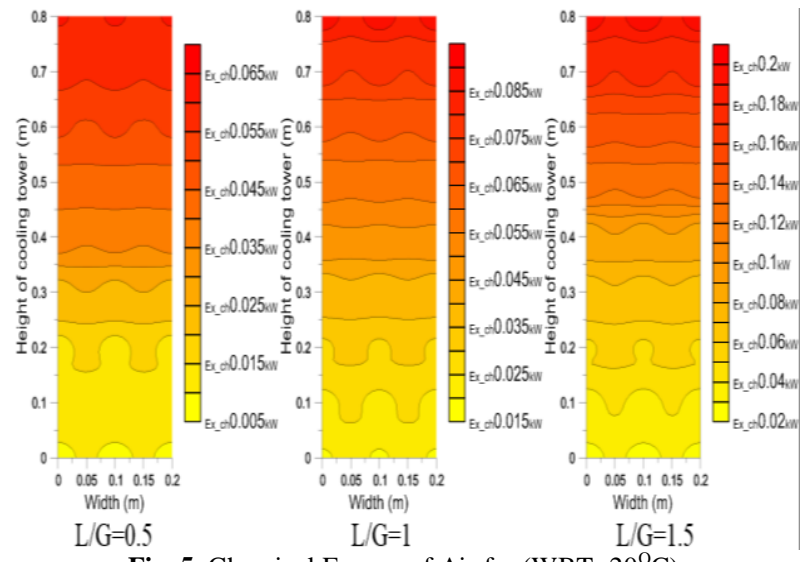

Fig. 5: Chemical Exergy of Air for $\left(\mathrm{WBT}=20^{\circ} \mathrm{C}\right)$. 


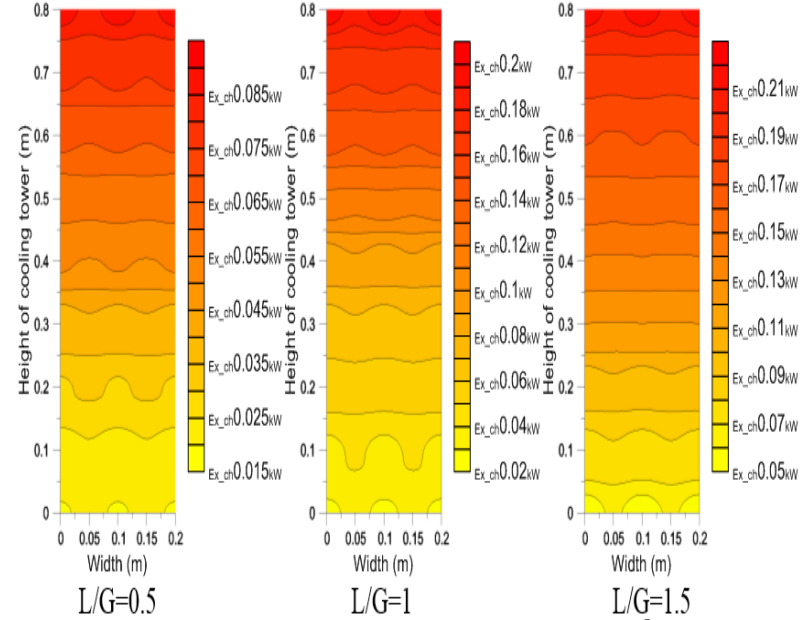

Fig. 6: Chemical Exergy of Air for $\left(\mathrm{WBT}=22^{\mathrm{O}} \mathrm{C}\right)$.

The influence of thermal exergy of air by inlet air wet bulb tempera-ture (WBT) and the ratio of water mass flow rate to air mass flow rate is shown in figures [7-8] and [9]. The thermal exergy of air tends to decrease upward from the bottom to the top of the cooling Tower. It can be noticed that the thermal exergy of air is directly propor-tional with inlet air wet bulb temperature (WBT) and the ratio of water mass flow rate to air mass flow rate (L/G). This because any increase in (WBT) of inlet air causes an increase in enthalpy poten-tial between the saturated steam and the surroundings. Also the increase in $(\mathrm{L} / \mathrm{G})$ leads to higher heat transfer.
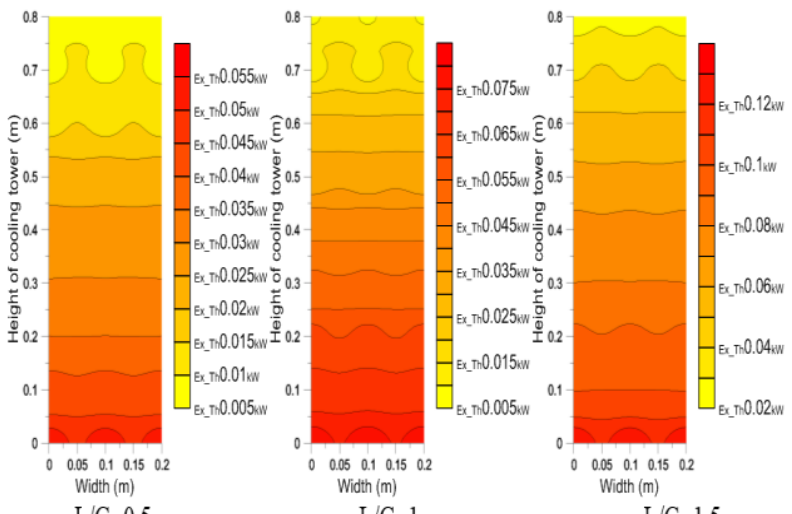

$\mathrm{G}=0.5$

$\mathrm{L} / \mathrm{G}=1$

$\mathrm{L} / \mathrm{G}=1.5$

Fig. 7: Thermal Exergy of Air for $\left(\mathrm{WBT}=18^{\mathrm{O}} \mathrm{C}\right)$.
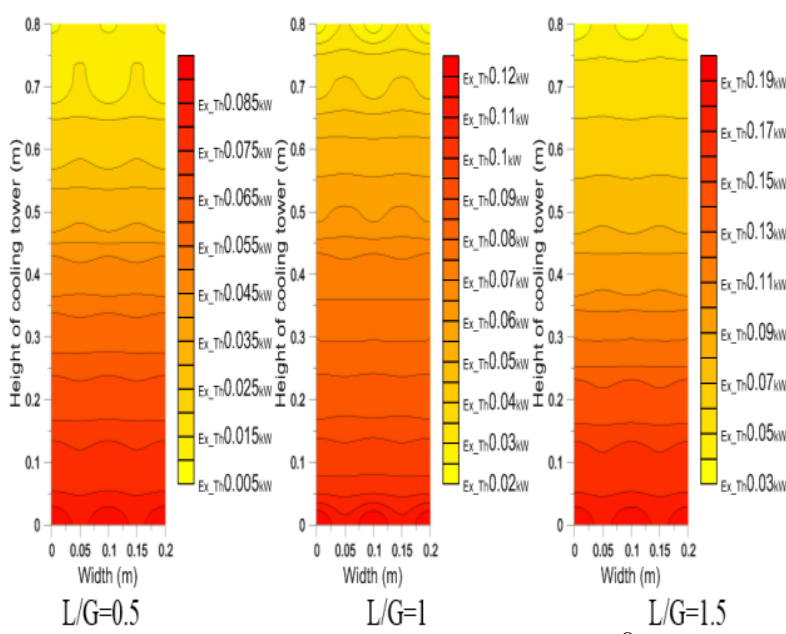

$\mathrm{L} / \mathrm{G}=1.5$

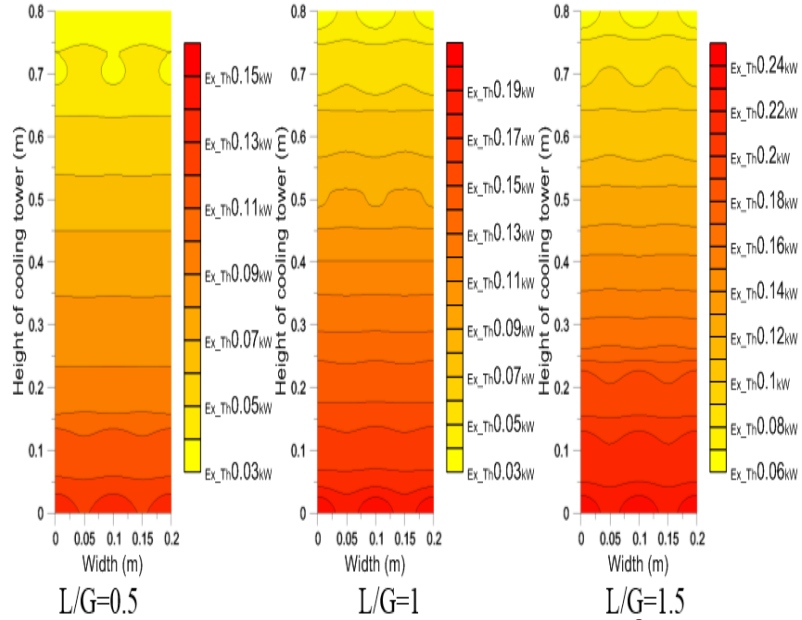

Fig. 9: Thermal Exergy of Air for $\left(\mathrm{WBT}=22^{\circ} \mathrm{C}\right)$.

Figures 10-11 and 12 present the effect of (WBT) of inlet air and ratio of water mass flow rate to air mass flow rate $(\mathrm{L} / \mathrm{G})$ on the exergy of water. It is clear that the exergy of water decreases downward from top to the bottom of the cooling tower. This is because the temperature of flowing flow water is higher at the top of the cooling tower than at the bottom. Also the exergy of water increases as (WBT) on inlet air and the ratio of water mass flow rate to air mass flow rate $(\mathrm{L} / \mathrm{G})$ increase.

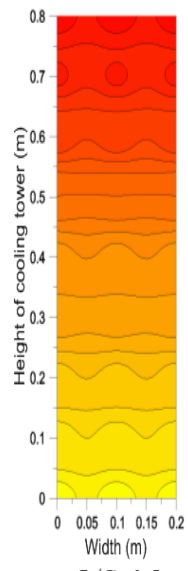

$\mathrm{L} / \mathrm{G}=0.5$

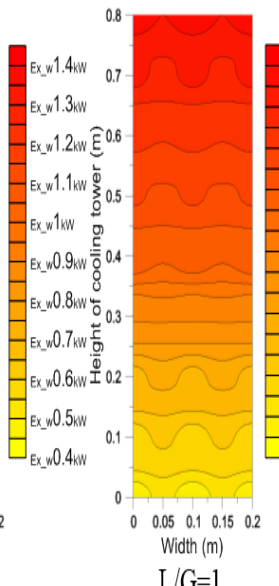

$\mathrm{L} / \mathrm{G}=1$

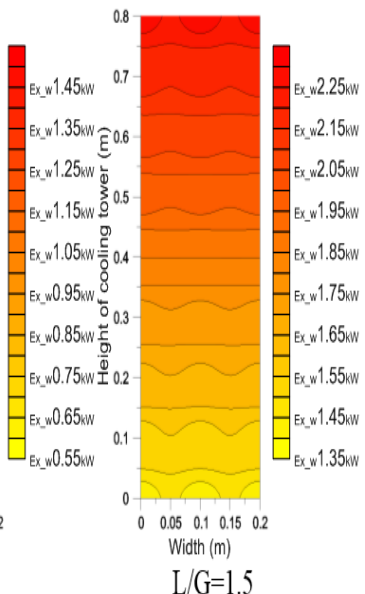

$\mathrm{L} / \mathrm{G}=1.5$
Fig. 10: Exergy of Water for $\left(\mathrm{WBT}=18^{\circ} \mathrm{C}\right)$.
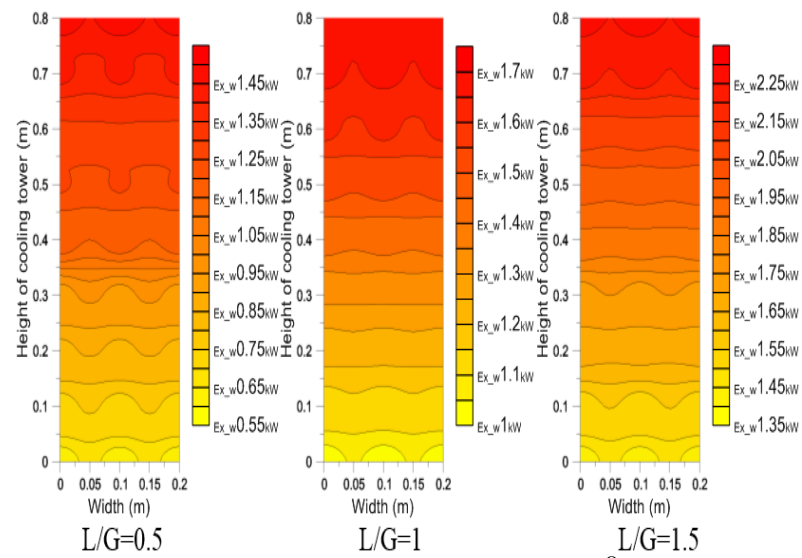

Fig. 11: Exergy of Water for $\left(\mathrm{WBT}=20^{\circ} \mathrm{C}\right)$

Fig. 8: Thermal Exergy of Air for $\left(\mathrm{WBT}=20^{\circ} \mathrm{C}\right)$. 


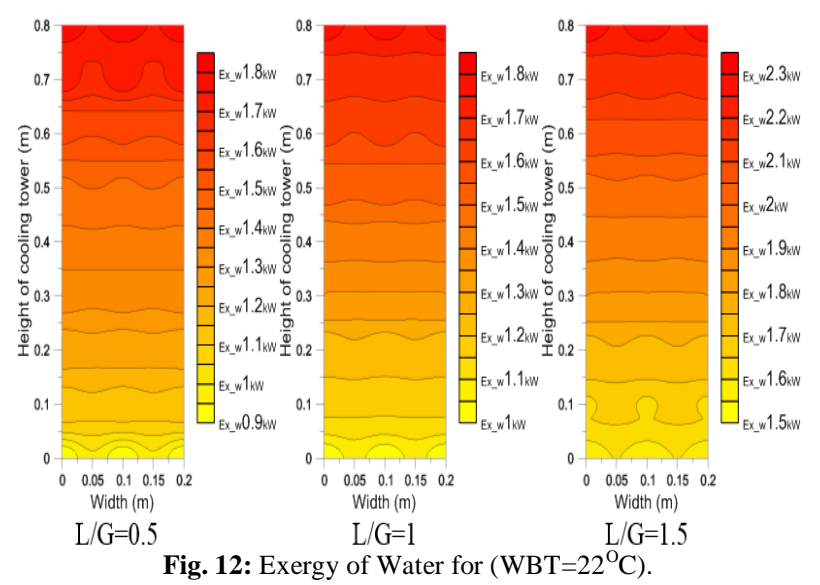

Figures [13-14] and [15] present the effect of (WBT) of inlet air and the ratio of water mass flow rate to air mass flow rate (L/G) on the exergy destruction. It is obvious that the exergy destruction de-creases downward from the top to the bottom of cooling tower. The exergy destruction increases with the increase of (WBT) of inlet air and the ratio of water mass flow rate to air mass flow rate $(\mathrm{L} / \mathrm{G})$. This is because the higher (WBT) of inlet air leads to higher dead temperature and evaporation losses, While the higher (L/G) ratio leads to higher entropy generation caused by evaporation.

Figures 16, 17 and 18 present the effect of (WBT) of inlet air and (L/G) ratio on the exergy energy. The results show that the exergy energy decreases upward from the bottom to the top of the cooling tower because the exergy destruction increases downward from the top to the bottom of the cooling tower. Also the exergy efficiency decreases as (WBT) of inlet air increases

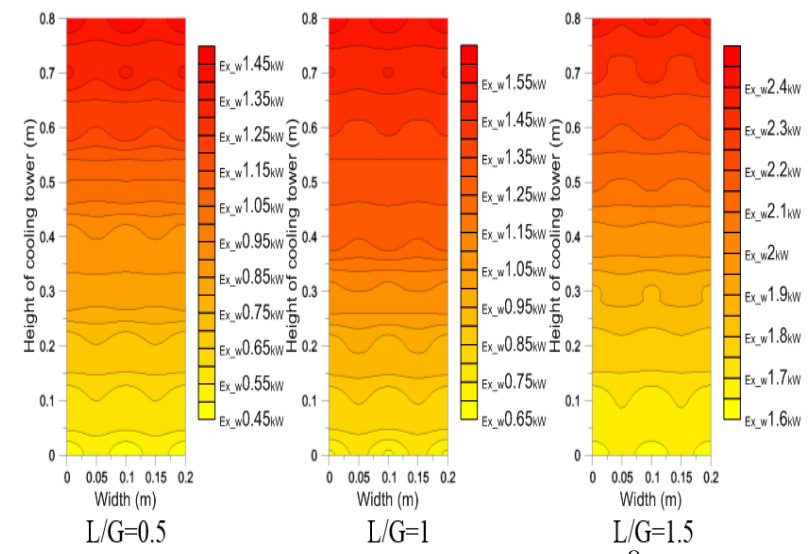

Fig. 13: Exergy Destruction for $\left(\mathrm{WBT}=18^{\circ} \mathrm{C}\right)$

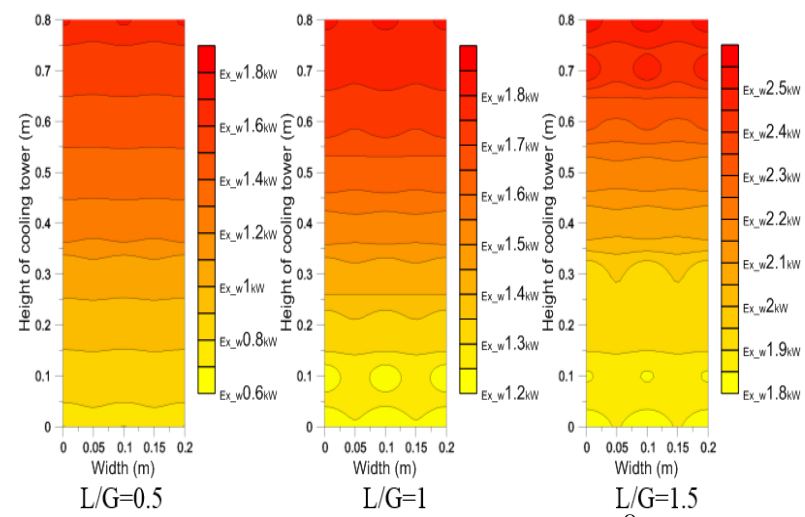

Fig. 14: Exergy Destruction for $\left(\mathrm{WBT}=20^{\circ} \mathrm{C}\right)$.

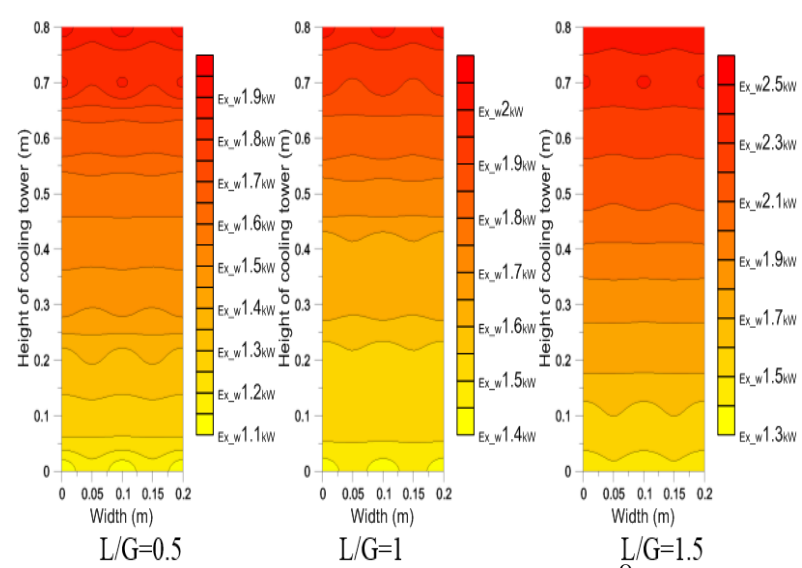

Fig. 15: Exergy Destruction for $\left(\mathrm{WBT}=22^{\circ} \mathrm{C}\right)$.

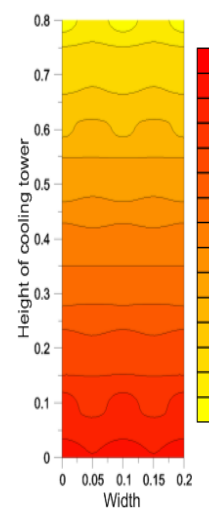

$\mathrm{L} / \mathrm{G}=0.5$

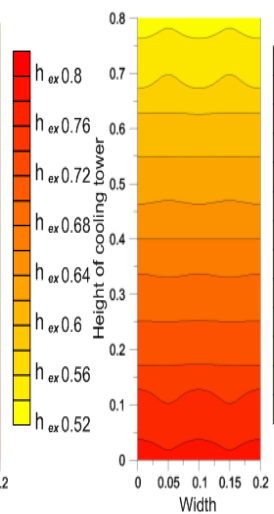

$\mathrm{L} / \mathrm{G}=1$

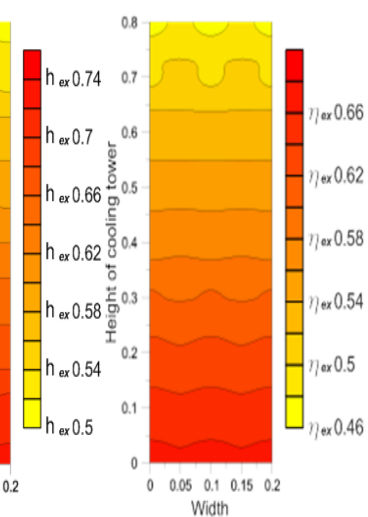

$\mathrm{L} / \mathrm{G}=1.5$
Fig. 16: Exergy Efficiency for $\left(\mathrm{WBT}=18^{\circ} \mathrm{C}\right)$.

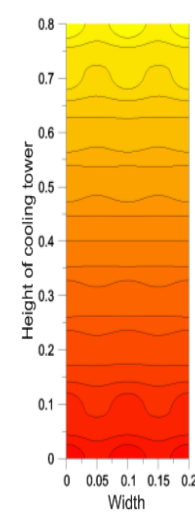

$\mathrm{L} / \mathrm{G}=0.5$

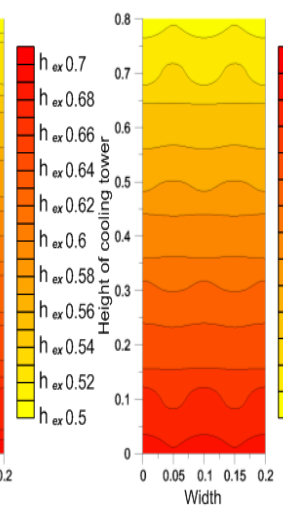

$\mathrm{L} / \mathrm{G}=1$

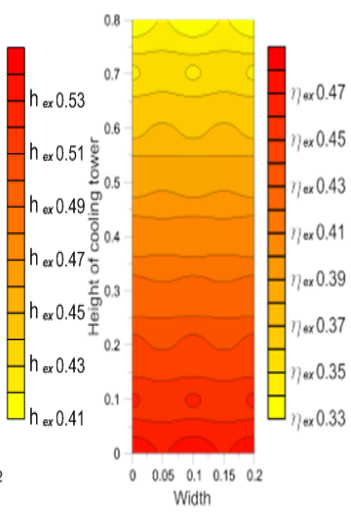

$\mathrm{L} / \mathrm{G}=1.5$
Fig. 17: Exergy Efficiency for $\left(\mathrm{WBT}=20^{\circ} \mathrm{C}\right)$.
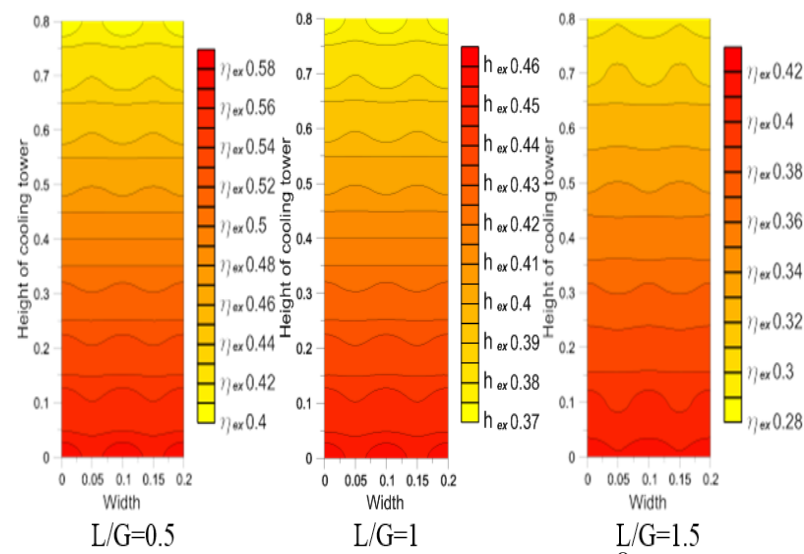

Fig. 18: Exergy Efficiency for $\left(\mathrm{WBT}=22^{\circ} \mathrm{C}\right)$. 


\section{Conclusions}

The exergy analysis model of cooling tower was developed by using engineering equation solver (EES) program, which is validated with the experimental data that reported from cooling tower device. It is can be explained by the study that:

1- The chemical exergy of air increases from bottom to the top of the cooling tower.

2- The thermal exergy of air decreases from the bottom to the top of the cooling.

3- The exergy of water decreases from top to the bottom of the cooling tower.

4- The exergy destruction decreases from bottom to the top of the cooling tower.

5- The exergy efficiency decreased from top to the bottom of the cooling.

6- The exergy destruction increases as the inlet wet bulb temperature (WBT) of air and water-air flow rate ratio $(\mathrm{L} / \mathrm{G})$ increase

7- The exergy efficiency decreases as the inlet wet bulb temperature (WBT) of air and water-air flow rate ratio $(\mathrm{L} / \mathrm{G})$ increase

\section{Nomenclature}

\section{A Area $\left(\mathrm{m}^{2}\right)$}

$\mathrm{cp}_{\mathrm{a}} \quad$ Specific heat of air $(\mathrm{kJ} / \mathrm{kg} . \mathrm{k})$

$\mathrm{cp}_{\mathrm{v}} \quad$ Specific heat of vapor $(\mathrm{kJ} / \mathrm{kg} . \mathrm{k})$

$\mathrm{cp}_{\mathrm{w}} \quad$ Specific heat of water $(\mathrm{kJ} / \mathrm{kg} . \mathrm{k})$

$\mathrm{Ex}_{\mathrm{a}, \mathrm{th}} \quad$ Thermal exergy of air $(\mathrm{kW})$

$\mathrm{Ex}_{\mathrm{a}, \mathrm{ch}} \quad$ Chemical exergy of air $(\mathrm{kW})$

$\mathrm{Ex}_{\text {dest. }}$ Total exergy destruction $(\mathrm{kW})$

$\mathrm{Ex}_{\mathrm{w}} \quad$ Exergy of water $(\mathrm{kW})$

$\mathrm{G} \quad$ Air flow rate $(\mathrm{kg} / \mathrm{s})$

$\mathrm{h}_{\mathrm{a}} \quad$ Enthalpy of the air $(\mathrm{kJ} / \mathrm{kg})$

$\mathrm{h}_{\mathrm{a}, \mathrm{s}} \quad$ Saturated enthalpy of air $(\mathrm{kJ} / \mathrm{kg})$

$\mathrm{h}_{\mathrm{dif}} \quad$ Mass transfer coefficient $\left(\mathrm{kg} / \mathrm{m}^{2} \mathrm{~s}\right)$

$\mathrm{h}_{\mathrm{f}, \mathrm{w}} \quad$ Saturated liquid enthalpy of water $(\mathrm{kJ} / \mathrm{kg})$

$\mathrm{L} \quad$ Water flow rate $(\mathrm{kg} / \mathrm{s})$

$\mathrm{q}_{\mathrm{t}} \quad$ Total heat transfer $(\mathrm{kW})$

$\mathrm{q}_{\mathrm{l}} \quad$ Latent heat transfer $(\mathrm{kW})$

$\mathrm{q}_{\mathrm{s}} \quad$ Sensible heat transfer $(\mathrm{kW})$

$\mathrm{R}_{\mathrm{a}} \quad$ Air gas constant (kJ/kg.K)

$\mathrm{R}_{\mathrm{v}} \quad$ Vapor gas constant $(\mathrm{kJ} / \mathrm{kg} . \mathrm{K})$

$\mathrm{T}_{\mathrm{a}} \quad$ Air temperature $\left({ }^{\circ} \mathrm{C}\right)$

$\mathrm{T}_{\mathrm{o}} \quad$ Dead state temperature $\left({ }^{\circ} \mathrm{C}\right)$

$\mathrm{T}_{\mathrm{w}} \quad$ Water temperature $\left({ }^{\circ} \mathrm{C}\right)$

\section{Greek letters}

$\eta_{\mathrm{ex}} \quad$ Exergy efficiency $(\%)$

$\emptyset_{\mathrm{o}} \quad$ Relative humidity of the air at dead state Temperature (-)

$\Omega \quad$ Moisture content (kgw/kga)

\section{Subscripts}

a Air

sat Saturated of air

dest Destruction

CV Control volume

$\mathrm{N} \quad$ Number of section

\section{References}

[1] Navid Bozorgan and Nariman Bozorgan, ,Heat and Mass Transfer Evaluation and Exergy Analysis in the Counter Flow Wet Cooling Tower of Khuzestan Steel Company (KSC), International J Advanced Design and Manufacturing Technology, Vol. 5 (2012), No. 3, pp 83-92.

[2] Hui, S. C. M. and Wong, H. Y. K, Exergy analysis of cooling towers for optimization of HVAC systems, the Hunan-Hong Kong Joint Symposium, 2011, pp. 41-51.

[3] T. Muangnoi W. Asvapoositkul S.Wongwises, An exergy analysis on the performance of a counterflow wet cooling tower, Applied Thermal Engineering 27 (2007), pp 910-917 https://doi.org/10.1016/j.applthermaleng.2006.08.012.
[4] A. Ataei, M. H. Panjeshahi and M. Gharaie, Performance Evaluation of Counter-Flow Wet Cooling Towers Using Exergetic Analysis, Trans. Can. Soc. Mech. Eng., 32 (2008), p.p 499 -511.

[5] Navid Bozorgan 'Exergy Analysis of Counter Flow Wet Cooling Tower in Khuzestan Steel Co", Journal of Mechanical Research and Application, Vol. 2 (2010), pp31-37.

[6] Khan, J. U. R.; Yaqub, M.; Zubair, S. M., Performance characteristics of counter flow wet cooling towers", Energy Conversion and Management 44 (2003) 2073-2091 https://doi.org/10.1016/S01968904(02)00231-5.

[7] A. H. N. Khalifa, Thermal and Exergy Analysis of Counter Flow Induced Draught Cooling Tower, International Journal of Current Engineering and Technology, Vol.5 (2015), No.4, p.p2868-2873.

[8] Q. S. Mahdi and H. M. Jaffal , Energy and Exergy Analysis on Modified Closed Wet Cooling Tower in Iraq", Al-Khwarizmi Engineering Journal, Vol. 12 (2016), No. 2, P.P. 45- 59.

[9] W. Stoecker Refrigeration and air conditioning, 2nd Edition, McGraw-Hill 1982.

[10] M. Zunaid, Q. Murtaza and S. Gautam, Energy and performance analysis of multi droplets shower cooling tower at different inle water temperature for air cooling application, Applied Thermal Engineering, Vol. 121 (2017) P.P 1070-1079.

[11] A. Niksiar and A. Rahimi, Energy and exergy analysis for cocurren gas spray cooling systems bottom on the results of mathematical modeling and simulation, Energy 34 (2009) p.p14-21 https://doi.org/10.1016/j.energy.2008.09.009. 